\title{
The Determinants of Capital Structure on China-Listed Construction Companies
}

\author{
Chandra Setiawan \\ chandra@president.ac.id \\ Management Study Program, Faculty of Business \\ President University, Cikarang, Indonesia \\ Qu Yumeng \\ qym0921@gmail.com \\ Management Study Program, Faculty of Business \\ President University, Cikarang, Indonesia
}

\begin{abstract}
Contruction companies in China debt to asset ratio around $76.16 \%$ to $82.67 \%$ compared to other countries in average below $40 \%$. Therefore, the objective of this research is to find out the determinants of the capital structure of listed construction companies in China. By employing the panel multiple regression model to meet the research objective. Through purposive sampling technique 10 listed companies in the construction industry from 2012 to 2019 are selected as samples, so there are 80 observations sample. The variable used to proxy capital structure is total debt ratio, and the independent variables are profitability, asset tangibility, firm size, growth opportunities, non-debt tax shield, interest rate and inflation rate. Among the independent variables been tested, the results reveal that five independent variables, except non-debt tax shield and inflation rate have a significant impact toward capital structure. Interest rate is the most significant influence variable. Finally, this research puts forward relevant suggestions for the optimization of the company's capital structure.
\end{abstract}

Keywords: capital structure; profitability; asset tangibility; firm size; growth opportunities; non-debt tax shield; interest rate; inflation rate

\begin{abstract}
Abstrak
Perusahaan-perusahaan konstruksi di China mempunyai rasio utang terhadap aset berkisar 76,16\% hingga 82,67\% dibandingkan dengan negara lain yang rata-rata di bawah $40 \%$. Oleh karena itu, penelitian ini bertujuan untuk mengetahui faktor-faktor yang mempengaruhi struktur modal pada perusahaan konstruksi yang menjual saham nya di pasar modal Tiongkok. Digunakan model regresi panel berganda untuk meraih tujuan penelitian. Melalui teknik purposive sampling sesuai kriteria yang ditentukan dipilih 10 perusahaan dalam industri konstruksi dari tahun 2012 hingga 2019 sebagai sampel. Variabel yang digunakan untuk memproksikan struktur modal adalah total debt ratio, dan variabel independennya adalah profitabilitas, asset tangibility, ukuran perusahaan, peluang pertumbuhan, non-debt tax shield, tingkat bunga dan tingkat inflasi. Di antara variabel independen yang diuji, hasilnya menunjukkan terdapat lima variabel independen, kecuali non-debt tax shield dan tingkat inflasi berpengaruh signifikan terhadap struktur modal. Suku bunga merupakan variabel yang berpengaruh paling signifikan. Akhirnya, penelitian ini mengedepankan saran yang relevan untuk optimalisasi struktur permodalan perusahaan.
\end{abstract}

Kata kunci: struktur modal; profitabilitas; asset tangibility; ukuran perusahaan; peluang pertumbuhan; non-debt tax shield; tingkat bunga dan tingkat inflasi

DOI: http://dx.doi.org/10.33021/jaaf.v\%vi\%i.1459 


\section{INTRODUCTION}

China's construction industry has grown quickly, yet in addition assumes an imperative part in the improvement of China's economy. The construction enterprises listed companies play a crucial role, effects on the roads, railroads, residential construction, harbor transportation aspect. The construction industry has already facilitated the innovation and supporting the establishment to the entire society where people's life is closely related to culture and education, sports, health facilities, and municipal utilities. Therefore, the rationality of the capital structure of the daily business operation for the construction enterprises plays a crucial role, and in turn affect its financing ability. The development of construction industry is closely related to people's lives, and provided more jobs for the employment market pull and contribute to the development of the whole economic market, promote the construction of industry associations to further improve and progress. Construction firms have become the pillar industries driving economic growth (Gunardi et al, 2020). Empirical evidence shows that endeavors in various trademark businesses by and large pick distinctive capital structures, yet coherently, there is an ideal capital structure to amplify the venture esteem. The unreasonable portion of obligation capital structure builds the danger of insolvency, which makes financing more troublesome. Subsequently, the capital structure of construction enterprises is not optimistic (Gunardi et al, 2020).

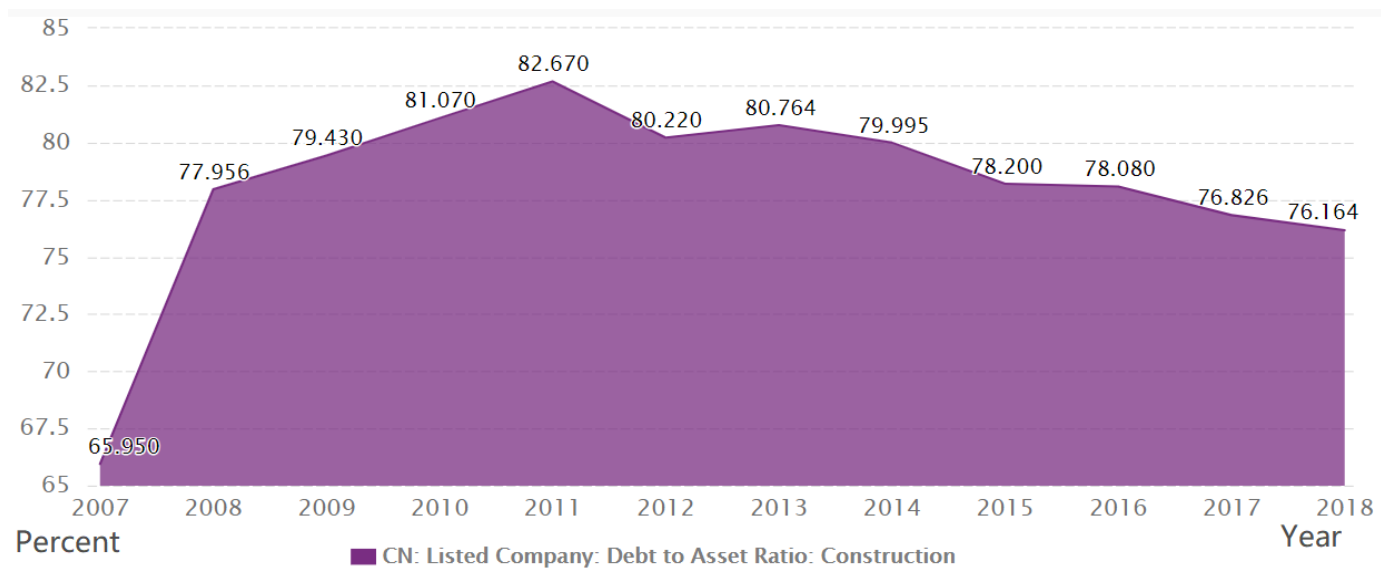

Figure 1. Debt to Asset Ratio of Construction Companies in China, 2007-2018 Source: China Securities Regulatory Commission, 2020

It revealed from Figure 1 that the debt-to-asset ratio of listed companies in China's construction industry is the biggest at $82.670 \%$. In December 2018, the ratio was $76.164 \%$, which decreased compared with the data in December 2017. Based on the data above the debt portion is more than $50 \%$, therefore the risks of the Construction companies are relatively high.

The choice of capital structure is a significant aspect of the undertaking monetary technique since the capital structure can be viewed as one of the money related centers of an endeavor. The capital structure is viewed as the premise of a company's monetary position, is the estimation of the endeavor's leaser's privileges and value and the comparing relationship. It affects the corporate governance structure, capital costs and operational risks, and determines the ability to repay debt (Jiang et al, 2018). However, if a reasonable financial leverage effect is generated, the economic benefits of enterprises can be improved and the value of enterprises can be increased. 


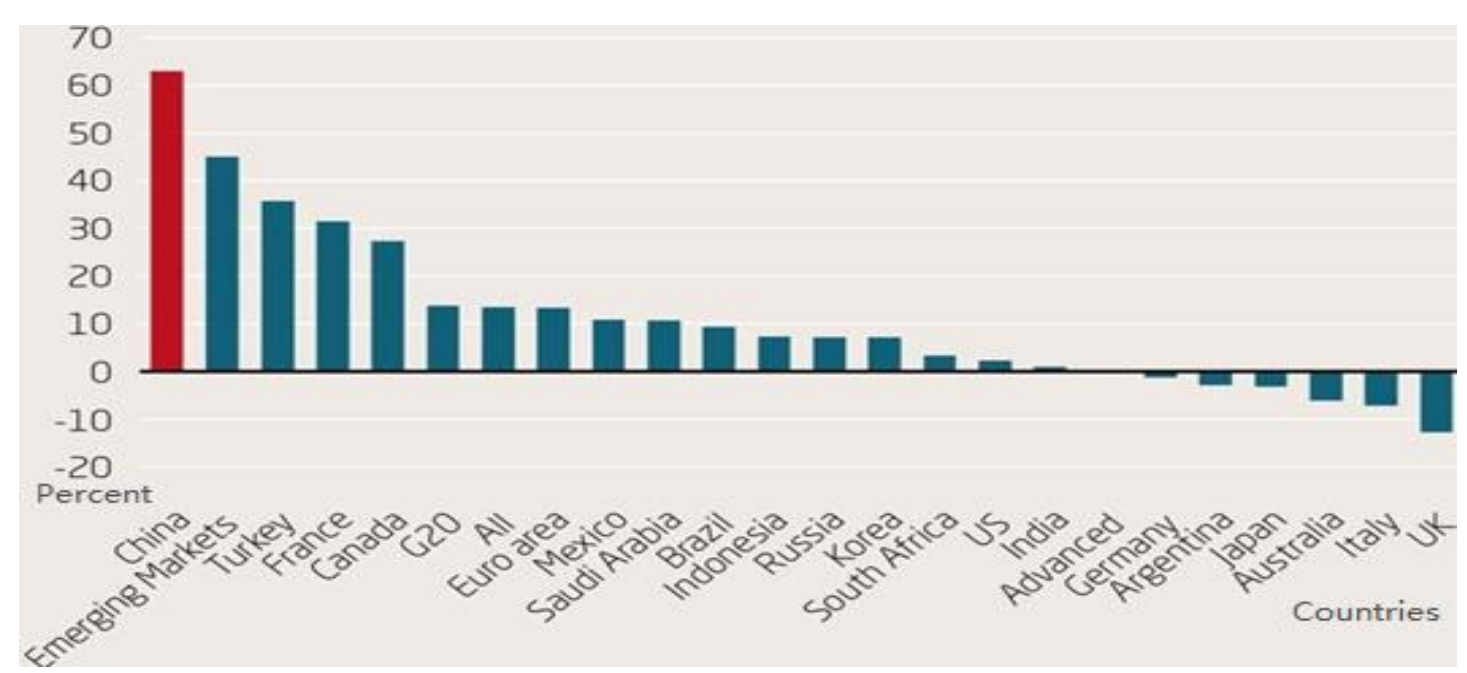

Figure 2. Percentage of Change of Corporate Debt to GDP, over 2008Q1-2018Q1 Source: Guonan ,2019

As revealed at Figure 2 China is quite different from other countries' listed companies. China's ratio is more than 60 percent, while the rest of the world is below 40 percent. China's listed companies now have one of the highest ratios of corporate debt to GDP compared to other countries in the world.

The capital structure is the foundation of the enterprise's financial condition. The value of the capital structure reflects the enterprise's equity and creditor's rights. It affects the corporate governance structure and determines the ability of enterprises to repay debts, obtain profits and raise funds. Reasonable, capital structure can effectively play the adjusting role of financial leverage, help enterprises to control risks, so that enterprises can obtain greater financial freedom. Therefore, capital structure is the core of enterprises (Berk \& DeMarzo, 2017). To study how to establish the optimal capital structure is important. There are many researchers have made empirical analysis on the factors affecting capital structure from multiple perspectives and obtained many research results. According to previous studies, several factors can affect the capital structure. These variables are profitability, asset tangibility, firm size, growth opportunities, non-debt tax shields, interest rate and inflation rate. Mohammed et al (2017) utilizes ROA as a specialist for profitability. Asset tangibility refers to a fixed asset owned by a company that exists in physical form and has monetary value and can be used as collateral for a loan. Firm size is the size or the total asset of the company owned and gives impact to the company value. Change of total assets is used as proxies for growth opportunities. Singh (2016) utilized the proportion of corporate salary expense to working benefit as a specialist of non- debt tax shields (NDTS). Gunardi et al (2020) utilized the swelling rate as an intermediary for inflation. Julkid and Lau (2020) utilized the real lending rate as an intermediary for the interest rate.

The establishment and the development of capital market in China relatively new compared to developed countries, therefore, there are still many problems in the financial market and need to be studied the capital structure according to the actual situation in China and put forward suggestions to optimize the capital structure, to help listed companies to develop, improve the value of the company, and protect the interests of investors (Chen et al, 2019).

Based on the background as mentioned above, the researchers determine the objectives of this research as follow: To find out the partial and simultaneously effects of Profitability (ROA), asset tangibility (the ratio fixed assets over total assets), Firm size (natural logarithm 
of total assets), Growth opportunities (the percentage change of total assets), Non-debt tax shields (ratio of corporate income tax to operating profit), Interest rate towards capital structure (total debt ratio), Inflation rate towards capital structure (total debt total assets ratio).

\section{LITERATURE REVIEW}

\section{Capital Structure}

According to Sofat and Singh (2017), Donaldson, who first studied the sequence of financing in 1961, observes that firms do not seem to raise money according to a particular capital structure, preferring to do so in a preferred order: first internally, then debt, then equity. Meyers and Majluf first explained this in 1984, when they built on Ross's research and started from the premise of information asymmetry to establish the Optimal sequence financing theory (also known as the pecking order theory) based on the signaling hypothesis (Sofat \& Singh, 2017). With the increasing number of mergers and acquisitions among enterprises in the 1980s, capital structure theory began to be combined with the theory of public control rights, and capital structure theory based on corporate control rights emerged, among which Harris-Revive model, Stutz model and Israel model were the most agent (Miglo, 2016).

The optimal ownership share is the result of weighing any personal gains from controlling the company against the loss of capital value of its own shares. Conversely, Stutz model thinks the ideal capital structure is controlled by amplifying the interests of investors as opposed to supervisors. The end is that the ideal obligation level of the endeavor that turns into the objective of the merger is the one that boosts the estimation of the portions of outer speculators: the enterprise that becomes the target of the hostile merger will have more debt than the non-target enterprise. Israel thinks according to the debt contract, creditors enjoy a certain amount of take-over income, and the shareholders of the target enterprise and the shareholders of the acquiring enterprise can only bargain over the part of the income they have not promised to pay to the creditors in advance. The optimal debt level is the result of the balance between the expected acquisition income of the shareholders of the target enterprise and the possibility of the acquisition (Miglo, 2016).

The purported capital structure alludes to the piece and corresponding relationship of different wellsprings of long-haul capital raising. Capital structure is a compound framework made out of numerous elements, numerous factors, and numerous levels. In monetary hypothesis, capital structure is likewise called money related influence, which is partitioned into expansive sense and restricted sense because of various comprehension of "capital". Regarding "capital" as the source of all funds, the broad capital structure refers to the composition of all capital (including both long-term capital and short-term capital), that is, the composition of own capital and debt capital and their proportional relationship. If "capital" is defined as a source of long-term capital, the narrowly defined capital structure refers to the composition and proportional relationship of various long-term capitals (longterm debt capital and equity capital) of an enterprise, and short-term debt capital (because its changes are more repetitive). Operating capital management is to exclude short-term debt capital from the capital structure. It can be seen from the above that regardless of the initial explanation, the capital structure is to discuss the proportional relationship between equity capital and debt capital. In this research, capital structure is viewed as the proportion of total debt capital to total assets, that is, total debt ratio (Vo, 2017). 


$$
\text { Debt Ratio }=\frac{\text { Total Debts }}{\text { Total Assets }}
$$

The previous research by Setiawan \& Kodratillah (2017) reveal that tangibility, profitability, liquidity and exchange rate are adversely associated with debt-to-equity ratio, while undertaking size is decidedly related with debt-to-equity ratio. The interest rate has no significant relationship with the debt-to-equity ratio.

\section{Profitability}

Concurring to Setiawan \& Kodratillah (2017), profitability alludes to the capacity of an endeavor to acquire benefits over a period. Return on asset (ROA) is the most degree of profitability. The higher the ROA proportion is, the more grounded the capability is, hence, the way better the execution is. The higher the return on resources is, the way better the benefits are and the way better the utilization of resources are, demonstrating the solid capacity of the company to change over resources into net income. Therefore, in the event that a company needs to compete in this industry, it must have great execution and proficient way of operation. Companies can accomplish most extreme benefits and efficiency whereas remaining fiscally sound. Up until this point, there has been no concession to the connection among productivity and capital structure. Utilizing diverse capital structure hypotheses to dissect the impact of profitability on corporate budgetary influence, various ends will be drawn. From the viewpoint of capital structure insolvency, given the degree of operational danger, the monetary danger of obligation is moderately not genuine for an organization with solid benefit. Then again, the tradeoff hypothesis recommends that, all else being equivalent, beneficial organizations ought to get more as an end-result of an appealing duty shield, suggesting a positive connection among gainfulness and obligation levels. This research thinks about that return on asset is the intermediary for profitability (Jaafar et al, 2020).

$$
\text { Return on Assets }=\frac{\text { Net income }}{\text { Total Assets }}
$$

\section{Asset tangibility}

The benefits of an endeavor can be separated into tangible assets and intangible assets. Asset tangibility alludes to the extent of tangible assets in the total assets. The capital structure hypothesis by and large holds that the substantial quality of big business resources has a significant effect on the decision of capital structure, yet the impact course is not steady. As indicated by the agency cost hypothesis, there is an irreconcilable situation among investors and leasers. At the point when a venture gains obligation, it might be more anxious to put resources into high-hazard ventures, subsequently hurting the interests of lenders. In this manner, insightful leasers regularly request higher intrigue. In any case, if the organization has more substantial resources as insurance for acquiring, it is bound to get the positive loan fee from the borrower, along these lines lessening the expense of obligation. Consequently, the proportion of unmistakable resources is decidedly related with the degree of liabilities. The proportion of substantial resources is contrarily corresponded with the degree of liabilities. Despite the fact that there is incredible contention in principle, most exact examinations have reasoned that the proportion of unmistakable resources for absolute resources is emphatically related with the degree of corporate obligation. This research considers that fixed assets divided by total assets is the proxy for asset tangibility (Duan et al, 2019). 


\section{Firm size}

$$
\text { Asset tangibility }=\frac{\text { Fixed assets }}{\text { Total assets }}
$$

Size is a significant factor to be considered in the choice of capital structure of undertakings, and its effect on the debt proportion of endeavors is dubious. As indicated by the trade-off hypothesis, bankruptcy expense is fixed. With the expansion of organization size, its extent in big business esteem diminishes continuously. In this way, the higher the budgetary influence proportion is Agency cost Theory recommends that the size of the organization be more straightforward, give more data to banks, cost brought about by unbalanced data is less. So, a large organization than a little organization has a higher obligation proportion. This research thinks that the natural logarithm of total assets is the intermediary for firm size M'ng et (al, 2017).

\section{Firm Size $=$ Natural Logarithm of Total Assets}

\section{Growth opportunities}

Endeavors with high development potential have more prominent adaptability in activity. Ventures with high development potential have a place with rising businesses, and the advantages of such undertakings have higher versatility. Agent theory, bankruptcy expense and agency cost will increment with the expansion of the pliancy of benefits, yet then again, high development organizations have more noteworthy advancement potential and improvement possibilities, for high development firms, or more measure of capital development needs, and when the capacity of long haul financing is limited, the endeavor will in general get momentary obligation financing; moreover, with solid development potential, ventures additionally face moderately greater speculation opportunities, which will likewise make undertakings need a lot of assets. Since the expense of obligation financing is lower than value financing, ventures with solid development have moderately high obligation proportion. This research thinks about that difference in total assets is the intermediary for growth opportunities (Bendo, 2018).

\section{Non-debt tax shields}

$$
\text { Growth opportunities }=\frac{\text { Sales }_{t}-\text { Sales }_{t-1}}{\text { Sales }_{t-1}}
$$

Debt has the capacity of tax reduction. At the point when the expense rate increases, the assessment inclination of obligation will increment. In this manner, undertakings with a high assessment rate may generally have a high obligation proportion. For an assortment of reasons, the assessment shield impact of obligation financing is generally subtler for Chinese undertakings. Be that as it may, not just obligation financing can produce charge evasion pay, yet additionally non-obligation charge shields can assume a similar job. Diverse deterioration arrangements, devaluation life and all out fixed resources may cause various measures of deterioration between various endeavors or inside various timeframes for a similar venture. As per the arrangements of The Tax law of China, the deterioration separated by endeavors as per the arrangements might be incorporated into the cost and be ordered before charge. Notwithstanding where their cash is coming from some venture ventures, can tax cuts for the organization, for instance, speculation tax reduction, tax cuts for the devaluation of fixed resources, for example, endeavor's income will not diminish due to deterioration of fixed resources, however organizations do not need to pay charge in view of deterioration of fixed resources, speculation tax break have similar utility and the devaluation of fixed resources, this sort of duty proficient utility is known as the non-obligation charge shields. The replacement of non-obligation charge shields for intrigue cost assumes a function in deducting corporate assessment, which fills in for money related influence. Subsequently, 
organizations with countless non-debt tax shields utilize fewer obligations than those without these tax shields (Lei, 2020).

\section{Interest rate}

$$
\text { Non }- \text { debt tax shields }=\frac{\text { Depreciation }}{\text { Total assets }}
$$

Equity financing and debt financing are two kinds of external financing. These two financing methods are fungible to a certain extent, and enterprises' choice of which financing method mainly considers the degree of difficulty in obtaining funds and the size of financing costs. For listed companies in China, more consideration is given to the size of financing costs. The cost of issuing stock can be measured in various ways, such as return on equity, stock issuance, and so on. The expense of obligation financing principally relies upon the loan cost. Considering, the loan cost here alludes to the real interest rate. The real interest rate is equal to the ostensible interest rate minus the swelling rate. Hence, it very well may be accepted that when the genuine financing cost of credit rises, the expense of obligation financing rises, and ventures will receive greater value financing and lower budgetary influence proportion. This research considers that the legal lending rate of financial institutions is the proxy for the actual interest rate (Julkid \& Lau, 2020).

\section{Inflation rate}

For listed companies, long haul inflation prompts an exchange of genuine riches from lenders to investors. Its effect on capital structure in the accompanying angles: first, swelling expanded the organization's business hazard, making the organization the income from speculation ventures are not satisfactory, on the other hand, the sharp rise in inflation is the company's debt financing cost, thus causes listed companies prefer to equity investment, in short, high inflation, resulting in a loss of asset-liability ratio. This research considers that the consumer price index (CPI) of provinces and cities where listed companies are located is the proxy for the inflation rate (M'ng et al, 2017).

\section{Research Gap}

Referring to the previous findings of researchers revealed contrary results, such as Singh (2016) found that tangibility and profitability on total debt ratio, while undertaking size and growth opportunities were decidedly related with total debt ratio. The non-debt tax shield has no significant relationship with the total debt ratio. On the other hands, M'ng et al (2017) found that profitability affected capital structure for Malaysia and Singapore, however inconsequential for Thailand. Tangibility of assets affects capital structure for Malaysia and Singapore while insignificant for Thailand. Nonetheless, Cevheroglu-Acar (2018) found that non-debt tax shield and tangibility are critical determinants of the capital structure. The example of each exploration additionally contrasts across states with different seasons of perception. The distinction in factors utilized, perception period, test, and discoveries make the gaps among investigators. Hence, the reason for this research is to fill the gaps of the determinant variables affecting the dynamic of capital structure.

\section{Hypotheses}

The reason for this examination is to break down the elements affecting the capital structure of listed companies in China's construction industry. In view of the previous literatures as analyzed above, this research hypotheses the influence of profitability, asset tangibility, firm size, growth opportunities, non-debt tax shield, interest rate, and inflation rate towards capital structure (total debt ratio) on China's Construction listed companies. 


\section{RESEARCH METHOD}

Due to what needed by the study with numerical data in achieving the conclusion as research result, this research uses the quantitative method in support the effects from profitability, asset tangibility, firm size, growth opportunities, non-debt tax shields, interest rate and inflation rate toward capital structure on China-listed companies. After selecting the method, the researchers began to collect data from a variety of sources, such as the company's annual financial statements. The population in this research is China's firms recorded on the Shanghai stock trade, Shenzhen stock trade and Hong Kong stock trade. The population chosen from this study was intended to help the investigation to get better outcomes and proposals. Therefore, population was selected as one of the top 500 listed companies in China in 2020. Through the purposive sampling with the criteria as follow: The company must be a construction company and must be listed on the Shanghai and Shenzhen stock exchanges; The company must be listed in China's top 500 companies by market value; The company has published its quarterly financial statements from 2012 to 2019; The company's stock has never been suspended on the stock exchange. Based on the criteria or characteristics identified above, the researchers of this study have selected 10 construction companies from China's listed companies. Since the researchers using panel data, there are 80 total observation samples (time series $\mathrm{x}$ cross-section)

According to what stated in (Gupta, 2019), there are three kinds of information normally utilized in research, time arrangement, cross areas, and pooled or board information. Time arrangement information is characterized as information that has one object of perception within the hour of over one year. On the other hand, cross-section data is the opposite of time series data where cross section data has more than one observation object at the same time (Ghauri et al, 2020). While for the panel data is data which has more than one observation object and in a period of more than one year, or simply it is a combination of two data characteristics from time series and cross-section data (Gupta, 2019).

In connection with the need for analysis in this research, the data panel will be applied. Panel data is divided into two types of data panels based on the number of observations on each panel, there are balanced panels and unbalanced panels. This research will focus on balanced panels where the number of observations in each unit cross section is the same as the number of observations in the time series. In model test regression, there are three basic approaches in emphasizing the estimation (Ghauri et al, 2020): Common Effect, Fixed Effect, Random Effect. Therefore, there are two estimation techniques that can be used in determining the best model between common, fixed, and random effects. There are ChowTest and Hausman-Test, these two techniques are used to obtain the most appropriate and best model for estimating model test regression.

In this study panel multiple regression equation adopted to specify the explanatory variables' impact on capital structure. The seven independent variables used as follow: productivity $\left(\mathrm{X}_{1}\right)$, asset tangibility $\left(\mathrm{X}_{2}\right)$, firm size $\left(\mathrm{X}_{3}\right)$, growth opportunities $\left(\mathrm{X}_{4}\right)$, non-debt tax shields $\left(\mathrm{X}_{5}\right)$, interest rate $\left(\mathrm{X}_{6}\right)$ and inflation rate $\left(\mathrm{X}_{7}\right)$. Meanwhile, capital structure is becoming the dependent variable (Y) in this research. The panel multiple regression is formulated as follow:

$Y_{i, t}=\alpha+\beta_{1} X_{1 i, t}+\beta_{2} X_{2 i, t}+\beta_{3} X_{3 i, t}+\beta_{4} X_{4 i, t}+\beta_{5} X_{5 i, t}+\beta_{6} X_{6 i, t}+\beta_{7} X_{7 i, t}+\varepsilon_{i, t}$

Where: $Y=$ capital structure, $\alpha=$ intercept, $\left(\beta_{1}\right.$ to $\left.\beta_{7}\right)=$ regression coefficient, $X_{1}$ profitability, $X_{2}=$ asset tangibility, $X_{3}=$ firm size, $X_{4}=$ growth opportunities, $X_{5}=$ non-debt tax shields, $\mathrm{X}_{6}=$ interest rate, $\mathrm{X}_{7}=$ inflation rate, and $\varepsilon=$ random error. 
The classical assumption test includes many tests, for normality test, heteroskedasticity test; multicollinearity test and autocorrelation test are applied in this research. T-test employed to find out the effect of each independent toward dependent variable. F-Test will be used to determine how simultaneously independent variables are having a significant effect on the dependent variable (Gupta, 2019). The coefficient of determination $\left(\mathrm{R}^{2}\right)$ defined as a measurement to explain variations of dependent variable. The impact of the sample size (n) and the quantity of autonomous factors (k) in the variables is considered in the changed $\mathrm{R}^{2}$, therefore, to determine how powerful the independent variables variation to explain the variation of dependent variable in this research committed to emphasize adjusted $\mathrm{R}^{2}$ (Mishra et al, 2019).

\section{RESULTS AND DISCUSSION}

\section{Descriptive Analysis}

This part describes a brief quantitative data summary. It shows the number of observations and the variation of the data.

Table 1. Descriptive statistics of dependent and independent variables

\begin{tabular}{lrrrrrr}
\hline \multicolumn{1}{c}{ Items } & $\mathrm{N}$ & Minimum & Maximum & Mean & Std. Deviation & Variance \\
\hline Y=debt ratio & 80 & .50 & .85 & .7377 & .07972 & .006 \\
X1=Profitability & 80 & -.01 & .14 & .0276 & .01944 & .000 \\
X2=Asset tangibility & 80 & .02 & .18 & .0792 & .04208 & .002 \\
X3=Firm size & 80 & 10.00 & 14.53 & 12.5133 & 1.26590 & 1.603 \\
X4=Growth Opportunities & 80 & -.26 & .65 & .0980 & .12412 & .015 \\
X5=Non-debt tax shields & 80 & .00 & .05 & .0135 & .01166 & .000 \\
X6=Interest rate & 80 & .04 & .06 & .0495 & .00724 & .000 \\
X7=Inflation rate & 80 & 1.01 & 1.03 & 1.0231 & .00652 & .000 \\
Valid N (list wise) & 80 & & & & & \\
\hline
\end{tabular}

Source: Proceed data by SPSS 23.0

\section{Debt ratio $(Y)$}

The mean of debt ratio resulted as revealed on Table 1 equal 0.7377 , minimum value is 0.50 gained by Sany Heavy Equipment International Holdings Company Limited in 2019, which brought about by the absolute obligation of this organization is little, while its complete value is monstrous. The maximum is in the amount of 0.85 by China Railway Group Limited in 2013, this is caused by this company had a larger total debt compared to the total equity. This marvel caused the organization's capital structure to be very high. The standard deviation of an organization's capital structure is 0.079 less than mean value, therefore the data is stable.

\section{Profitability $\left(X_{1}\right)$}

The mean profitability (ROA) resulted 0.0276 , minimum value is -0.01 gained by Metallurgical Corporation of China Ltd in 2012. The maximum is in the amount of 0.140. The standard deviation of profitability (ROA) is 0.01944 and shows the stability of ROA relatively during the period of observation.

Asset tangibility $\left(X_{2}\right)$

Asset tangibility means value is 0.0792 . Minimum value is 0.02 which owned by Sany Heavy Equipment International Holdings Company Limited in 2019, demonstrates this 
organization has the most reduced extent of fixed resources of their complete resources claimed, contrasted with different organizations. In other words, this company has the lowest investment of its fixed assets during the research. The maximum value amounted to 0.18 by CSSC Offshore \& Marine Engineering (Group) Company Limited in 2016, representing this company has the highest percentage measurement of its fixed assets investment of their total assets during this research. The standard deviation of asset tangibility is 0.04208 .

Firm size $\left(X_{3}\right)$

Firm size means value is 12.5133 . Minimum value is 10.00 by CSSC Offshore \& Marine Engineering (Group) Company Limited in 2012. Maximum value experienced by CITIC LIMITED in 2019 in amount of 14.53, implies a large firm with better performance and lower asset volatility compared to other companies. The standard deviation is 1.26590 shows the stability of Firm Size relatively during the period of observation.

Growth Opportunities $\left(X_{4}\right)$

Growth opportunities had its mean value amounted to 0.0980, the minimum value is -0.26 owned by CSSC Offshore \& Marine Engineering (Group) Company Limited in 2017. Maximum value is 0.65 by Sany Heavy Equipment International Holdings Company Limited in 2017. This factual outcome shows there is an uncommon lessening in deals development. The standard deviation of development openings is 0.12412 .

Non-debt tax shields $\left(X_{5}\right)$

Non-debt tax shields had its mean value amounted to 0.0135 , the minimum value is 0.00 owned by China Railway Construction Corporation Limited in 2013. Maximum value is 0.050 by CITIC LIMITED in 2013. The standard deviation of non-debt tax shields is 0.01166 . That means this variable is stable.

Interest rate $\left(X_{6}\right)$

The mean of interest rate resulted 0.04950 , minimum value is 0.044 , The maximum is in the amount of 0.060 . The standard deviation of interest rate is 0.00724 . That means this variable is stable.

Inflation rate $\left(X_{7}\right)$

The mean inflation rate resulted in 1.0231 , minimum value is 1.01 . The maximum is in the amount of 1.03. The standard deviation of inflation rate is 0.00652. It shows that China's macroeconomic situation in recent years is relatively stable, with small annual fluctuation range.

\section{Panel Data Model Selection}

In data analysis, the regression model with panel data could be assessed by three basic approaches which are the common effect, fixed effect, and random effect. Therefore, this research must pass the Chow test to select the right approach.

\section{Chow Test (Likelihood Ratio)}

Chow test is used to define between fixed or common to be applied in the research. The fixed effect is chosen if the dummy variables are significant towards dependent variable. The following table shows the Chow test result. 
Table 2. Chow Test

\begin{tabular}{cccc}
\hline Effect test & Statistic & d.f. & Prob. \\
\hline Cross - section F & 18.482637 & $(9.63)$ & 0.0000 \\
Cross - section Chi - square & 103.366974 & 9 & 0.0000 \\
\hline
\end{tabular}

Source: Proceed data by EViews 10

Regarding the table above, the value of probability in Chow test is significant at 0.000 which lower than the significant level of $\alpha=0.05$. Therefore, it can be concluded that this model uses fixed effect since the result is significant.

\section{Multiple Regression Analysis}

The following table shows the result from the regression. The value of t-test and p-value are added to ease the interpretation of the result.

Table 3. Multiple Regression Analysis

\begin{tabular}{llllll} 
Model & $\begin{array}{l}\text { Unstandardized } \\
\text { Coefficients B }\end{array}$ & Std. Error & $\begin{array}{l}\text { Standardized } \\
\text { Coef. Beta }\end{array}$ & t & Sig. \\
\hline (Constant) & 1.248 & 1.215 & & 1.027 & .308 \\
X1=Profitability & -1.272 & .396 & -.310 & -3.216 & .002 \\
X2=Asset tangibility & -.484 & .212 & -.255 & -2.280 & .026 \\
X3=Firm size & .022 & .007 & .343 & 3.064 & .000 \\
X4=Growth Opportunities & -.116 & .061 & -.181 & -1.898 & .042 \\
X5=Non-debt tax shields & -.329 & .576 & -.048 & -.571 & .570 \\
X6=Interest rate & -4.780 & 1.120 & -.434 & -4.269 & .001 \\
X7=Inflation rate & -.916 & 1.211 & -.075 & -.756 & .452
\end{tabular}

Dependent Variable: $\mathrm{Y}=$ Debt Ratio

R-squared $=0,8703$, Adjusted R-squared $=0.8373$

Source: Proceed data by SPSS 23.0 \& EViews 10

\section{The Influence of profitability towards debt ratio}

Based on T-test result (-3.216, Table 3) profitability has a negative and significant influence towards debt ratio. While more profitable companies are in better financial shape, are more accepting of the risks of debt, and financial institutions are more willing to offer loans of all maturities. At the present stage of building enterprise tend to through the issuance of shares to finance, and this is mainly due to China's securities market should be further perfect each rules and regulations, makes the issue of equity financing is too high price and almost no pressure has more significant advantages of share out bonus, and higher profitability of the company are more likely to meet the conditions of the issued shares, so those listed companies have lower debt ratio. This finding is consistent with the pecking order theory in capital structure where the construction companies in China market prefer to used internal financing rather than external financing. The outcome is comparative with the outcomes from past investigations done by (ALmuaither \& Marzouk, 2019) and (Bendo, 2018).

The Influence of asset tangibility towards debt ratio

Based on T-test result (-2.280, Table 3) Asset tangibility has a negative and significant influence towards debt ratio. There is a negative impact of asset tangibility towards total debt 
ratio. Theoretically, the higher the ratio of tangible assets, the stronger the solvency and the smaller the risk of creditors. However, due to the weakness of the real economy in recent years, the supply in many industries has exceeded the demand, increasing the capital risk. The higher the asset tangibility is, the lower the information asymmetry will be and the lower the equity financing cost will be. Therefore, these listed companies will have a lower debt ratio. The outcome is comparative with the outcomes from past investigations done by (M'ng et al, 2017) and (Gunardi et al, 2020).

\section{The Influence of firm size towards debt ratio}

Based on T-test result (3.064, Table 3) Firm size has a positive and significant influence towards debt ratio. There is a positive impact of firm size towards total debt ratio. This result is consistent with the trade-off theory and most Chinese empirical results, that is, large enterprises are easier to finance debt. Large-scale enterprises are more willing to adopt diversified business strategies to diversify risks and expect low bankruptcy costs. In addition, higher credit is also easier to meet the requirements of financial institutions, access to capital support. So those listed companies have higher debt ratio. The result is comparative with the result from past examinations done by Sofat \& Singh, 2017.

\section{The Influence of growth opportunities towards debt ratio}

Based on the T-test result (-1.898, Table 3$)$ the Growth opportunities have a negative and significant influence towards debt ratio. There is a negative impact of growth opportunities towards total debt ratio. This is contrary to the existing foreign research results. The reason may be that China's high-growth companies are mostly emerging industries and private enterprises, which have greater commercial risks and cannot get more policy support. In addition, according to the agency theory of corporate capital structure and free cash theory, managers have a tendency to pursue scale and expand scale, and investment decisions may be suboptimal in general, because it is to deprive the interests of creditors. The result is comparative with the result from the previous research done by (Jaafar et al, 2020) and (Boateng et al, 2017).

\section{The Influence of non-debt tax shields towards debt ratio}

Based on the T-test result (-.571, Table 3) reveals that Non-debt tax shields have a negative and not significant influence towards debt ratio. There is a insignificant negative influence of non-debt tax shields towards total debt ratio. The trade-off theory predicts that depreciation to total assets has a negative effect toward capital structure. The result is consistent with that. Therefore, there is a negative correlation between non-debt tax shield and debt ratio. The result is consistent with (Lei, 2020) and (M'ng et al, 2017).

\section{The Influence of interest rate towards debt ratio}

Based on the T-test result (-4.269, Table 3) shows that Interest rate has a negative and significant impact towards obligation proportion. In China, if the company is listed, basically all aspects of the conditions have been quite mature; in this case, it is easier for the company to obtain debt financing and equity financing. In addition, the interest rate in China is not completely determined by the market, so the current interest rate should be considered in choosing a financing method. The higher the credit financing cost is, the more intrigue the organization will pay for similar measures of advances, and the higher the advance cost will be, so the organization will pay off its obligation and favor value financing. Alternately, the lower the advance financing cost, the more obligations the company has because of the lower credit cost. In this manner, the genuine loan fee is contrarily connected with the obligation proportion. The result is comparable with the result from previous research done by (Julkid 
and Lau, 2020).

The Influence of inflation rate towards debt ratio

Based on the T-test result (-.756, Table 3) reveals that Inflation rate has a negative and insignificant influence towards debt ratio. The inflation rate is the increase of the average price level. The higher the inflation rate is, the lower the purchasing power of the same amount of money is. Therefore, for listed companies, the higher the inflation rate is, the less funds they can use to repay future debts, which is actually the transfer of wealth from creditors to shareholders. Thus, the variation of inflation rate has no impact to capital structure. The result is similar with (M'ng et al, 2017).

Simultaneous Influence of profitability, asset tangibility, firm size, growth opportunities, nondebt tax shields, interest rate and inflation rate towards debt ratio

The hypotheses state there is significant influence of profitability, asset tangibility, firm size, growth opportunities, non-debt tax shields, interest rate and inflation rate toward debt ratio simultaneously on Chinese-listed companies, the F-statistic on table 2 shows all the independent variables such as: profitability, asset tangibility, firm size, growth opportunities, non-debt tax shields, interest rate and inflation rate that used to define the influence toward debt ratio found to be significant on capital structure simultaneously. The coefficient of determination (Adjusted R-Squared) indicates the capital structure proxied by debt ratio is being explained by the chosen independent variables in amount of $83.7 \%$ and the remaining percentage which is $16.3 \%$ is influenced by other factors besides the independent variables conducted in this research.

\section{The Most Influence Significant Influence Factor towards debt ratio}

In order to define the most significant influence until the least significant of independent variables, it can be seen through the result of T-statistics. The higher of T-statistic value is, the most significant to dependent variable. Additionally, the significance influence level can be ordered based on the probability value of T-statistics, means the closer probability value to 0 , it has the higher significance influence toward the dependent variable.

The most significant variable influences debt ratio on Chinese-listed companies is interest rate. The probability value is the closest to 0 compared to others with value by 0.001 . And tmeasurement esteem is most elevated with the incentive by -4.2693. In this way, it reasons that Interest rate plays an important role in economic development and is an effective tool for the government to regulate the economy. The real loan interest rate has a significant effect on the optimal capital structure. The capital structure of the enterprise should be adjusted accordingly with the change of debt interest rate. The result is comparable with the outcomes from past examinations done by (Julkid and Lau, 2020).

\section{CONCLUSIONS AND RECOMMENDATION}

The objectives of this study is to find out the partial and simultaneously effects of Profitability (ROA), asset tangibility (the ratio fixed assets over total assets), Firm size (natural logarithm of total assets), Growth opportunities (the percentage change of total assets), Non-debt tax shields (ratio of corporate income tax to operating profit), Interest rate towards capital structure (total debt ratio), Inflation rate towards capital structure (total debt total assets ratio).

Based on the result of the multiple regression analysis, panel data method the researchers sum up the conclusions as follows: Profitability, Asset Tangibility, Growth opportunities, Interest rate have a negative and significant impact towards capital structure; while Firm size

DOI: http://dx.doi.org/10.33021/jaaf.v\%vi\%i.1459 
has a positive and significant impact towards capital structure on China's construction listed companies. On the other hands, Non-debt tax shields, and Inflation rate have a negative and insignificant impact towards capital structure on Chinese construction listed companies.

Based on F-test, simultaneously all the independent variables: Profitability, asset tangibility, firm size, growth opportunities, non-debt tax shields, interest rate and inflation rate influence on capital structure. It demonstrates the variation of the capital structure is being explained by the variety of independent variables $83.7 \%$. The results reveal that the changes of non-debt tax shields and inflation rate are not influence the equity financing. Interest on debt has the effect of income tax deduction, the higher the income tax, the more enterprises will use debt financing to take advantage of the larger tax shield effect. The result demonstrates that the higher the credit loan cost is, the more intrigue the company will pay for similar measures of advances, and the higher the advance cost will be, so the company will pay off its obligation and incline toward value financing. The result of the T-test demonstrates that the most significant variable impacts on capital structure of China construction listed companies is interest rate. When the economy is depressed, by lowering interest rates, firms are more likely to go into debt and invest more. Listed companies are the main investment subjects in the social economy, and their increased investment causes the demand of the whole society, thus stimulating the economic development. On the other hand, when the economy booms and causes serious inflation, interest rates can be raised to curb it. Interest rate, profitability, firm size and growth opportunities play an important role in economic development and is an effective tool for the government to regulate the economy. The conclusions of this research can be used as the basis for optimizing the capital structure of listed companies. When the interest rate changes, the enterprise should adjust the capital structure accordingly, therefore, the enterprise can make more reasonable financing, investment decisions and improve the value of the enterprise.

\section{REFERENCES}

ALmuaither, S., \& Marzouk, M. (2019). Determinants of capital structure: evidence from the UK. Journal of Modern Accounting and Auditing, 15(6), 261-292.

Bendo, M. V. B. (2018). Determinants of capital structure for Philippine publicly-listed companies. ISSN No. 2362-7832, 173.

Berk, J., \& DeMarzo, P. (2017). Corporate finance, 4th global ed. Harlow: Pearson.

Boateng, A., Cai, H., Borgia, D., Bi, X. G., \& Ngwu, F. N. (2017). The influence of internal corporate governance mechanisms on capital structure decisions of Chinese listed firms. Review of Accounting and Finance. 16(4).

Cevheroglu-Acar, M. G. (2018). Determinants of capital structure: empirical evidence from Turkey. J. Mgmt. \& Sustainability, 8(31).

Chen, Z., Harford, J., \& Kamara, A. (2019). Operating leverage, profitability, and capital structure. Journal of Financial and Quantitative Analysis, 54(1), 369-392.

Duan, Y., Wang, R., \& Zhou, W. (2019, October). Analysis of the dynamic impact of intangible assets on capital structure of listed companies in the construction industry. In IOP Conference Series: Earth and Environmental Science, 330(2), 022093). IOP Publishing.

Ghauri, P., Grønhaug, K., \& Strange, R. (2020). Research methods in business studies. Cambridge University Press.

Gunardi, A., Firmansyah, E. A., Widyaningsih, I. U., \& Rossi, M. (2020). Capital structure determinants of construction firms: does firm size moderate the results? Montenegrin Journal of Economics, 16(2), 93-100.

DOI: http://dx.doi.org/10.33021/jaaf.v\%vi\%i.1459 
Guonan Ma (2019). China's high and rising corporate debt. https://merics.org/en/report/chinas-high-and-rising-corporate-debt https://www.ceicdata.com/en/china/financial-data-of-listed-company-debt-to-assetratio/cn-listed-company-debt-to-asset-ratio-construction. August, 22, 2019

Gupta, S. C. (2019). Business statistics. India. Himalaya Publishing House Pvt. Ltd

Jaafar, M. N., Muhamat, A. A., Basri, M. F., \& Joreme, A. A. (2020). Determinants of capital structure among shariah compliant industrial product and services firms listed on Ace Market, Bursa Malaysia. Journal of Islamic Finance, 9(1), 024-034.

Jiang, J., Dong, F., \& Du, B. (2018). Analysis on the factors affecting the capital structure of small and medium-sized enterprises in China. American Journal of Industrial and Business Management, 8(1), 156-162.

Julkid, N. F. B., \& Lau, W. T. (2020). Capital structure decision: micro-and macroeconomic determinants in Malaysia. Sciences, 10(2), 76-86.

Lei, L. (2020). Research on the impact of tax shield effect on corporate capital structureempirical analysis based on a-share listed companies. Modern Economy, 11(1), 126139.

M'ng, J. C. P., Rahman, M., \& Sannacy, S. (2017). The determinants of capital structure: evidence from public listed companies in Malaysia, Singapore and Thailand. Cogent Economics \& Finance, 5(1).

Miglo, A. (2016). Capital structure in the modern world. Palgrave Macmilolan, Cham. eBook ISBN: 978-3-319-30713-8

Mishra, P., Pandey, C. M., Singh, U., Gupta, A., Sahu, C., \& Keshri, A. (2019). Descriptive statistics and normality tests for statistical data. Annals of cardiac an aesthesia, 22(1), 67.

Mohammed, R. I., Gawdan, K. M., \& Babela, I. S. (2017). Factors affecting capital structure of the banks listed on Iraqi stock (2009-2014). Humanities Journal of University of Zakho, 5(2), 487-495.

Setiawan, C., \& Kodratillah, O. I. (2017, February). Examining banks profitability and banks efficiency of islamic commercial banks in Indonesia. In Proceedings of 12th AsiaPacific Business Research Conference, 27-28.

Singh, D. (2016). A panel data analysis of capital structure determinants: an empirical study of non-financial firms in Oman. International Journal of Economics and Financial Issues, 6(4).

Sofat, R., \& Singh, S. (2017). Determinants of capital structure: an empirical study of manufacturing firms in India. International Journal of Law and Management 59(5).

Vo, X. V. (2017). Determinants of capital structure in emerging markets: evidence from Vietnam. Research in International Business and Finance, 40, 105-113. 